\title{
Respon Mahasiswa Proram Studi Pendidikan Matematika Universitas Flores pada Program MBKM
}

\author{
Sofia Sa'o ${ }^{1}$, Lely Suryani ${ }^{2}$, Hilaria M. Mbagho ${ }^{3}$, Agustina $\mathrm{Mei}^{4}$ \\ 1, 2, 3,4 Program Studi Pendidikan Matematika, Fakultas Keguruan dan Ilmu Pendidikan, Universitas Flores, \\ Jl. Sam Ratulangi No XX, Ende, Indonesia \\ saosofia39@gmail.com
}

\begin{abstract}
Merdeka Learn Campus Merdeka (MBKM) I fixed it design of the implementation of the curriculum for study programs based on the Indonesian National Qualifications Framework (KKNI). Merdeka Learning Merdeka Campus has a Teaching innovation so that it can produce students who are innovative, creative and at the same time can develop their potential in the chosen field. This study aims to determine the impact and perception of the implementation of Merdeka Learning Merdeka Campus in private universities; survey at the Mathematics Education Study Program, FKIP University of Flores This research is a descriptive study with a qualitative approach with a survey method. Data I fixed it from a population of 156 respondents who were students of the Mathematics Education Study Program at the University of Flores. Data were collected through a questionnaire. The data analysis technique started from data collection and then analyzed using descriptive analysis. The results of this survey research show that students in the mathematics education study program, Faculty of Teacher Training and Education (FKIP) University of Flores gave a positive response to the Independent Learning Campus (MBKM) program and have prepared themselves to take part in MBKM activities, especially teaching assistance programs at the Independen campus education units.
\end{abstract}

Keywords: Survey Method, Independent Learning Independent Campus, College Students

\begin{abstract}
Abstrak
Merdeka Belajar Kampus Merdeka (MBKM) merupakan desain lanjutan dari penerapan kurikulum program studi berbasis Kerangka Kualifikasi Nasional Indonesia (KKNI). Merdeka Belajar Kampus Merdeka ini terdapat suatu inovasi belajar sehingga dapat menghasilkaan mahasiswa yang inovatif, kreatif dan sekaligus dapat mengembangkan potensi dirinya dalam bidang yang dipilih. Penelitian ini bertujuan untuk untuk mengetahui dampak dan persepsi penerapan Merdeka Belajar Kampus Merdeka di perguruan tinggi swasta; survey pada Program Studi Pendidikan Matematika FKIP Universitas Flores Penelitian ini merupakan penelitian deskriptif dengan pendekatan kuantitatif dengan metode survei. Data diperoleh dari populasi yang berjumlah 156 responden yang merupakan mahasiswa Program Studi Pendidikan Matematika Universitas Flores. Data dikumpulkan melalui kuesioner. Teknik analisis data dimulai dari pengumpulan data kemudian dianalisis menggunakan analisis deskriptif. Hasil dari penelitian survey ini menunjukan bahwa mahasiswa pada program studi pendidikan matematika, Fakultas Keguruan dan Ilmu Pendidikan (FKIP) Universitas Flores memberikan respon yang positif terhadap program Merdeka Belajar Kampus Merdeka (MBKM) dan sudah menyiapkan diri untuk mengikuti kegiatan MBKM khususnya program asistensi mengajar di satuan pendidikan.
\end{abstract}

Kata kunci: Survei, Merdeka Belajar Kampus Merdeka, Mahasiswa

Copyright (c) 2022 Sofia Sa’o, Lely Suryani, Hilaria M. Mbagho, Agustina Mei

$\triangle$ Corresponding author: Sofia Sa'o

Email Address: saosofia39@gmail.com (Jl. Sam Ratulangi No XX, Ende, Indonesia)

Received 28 December 2021, Accepted 05 February 2022, Published 08 February 2022

\section{PENDAHULUAN}

Merdeka berarti bebas memilih alternatif kebijakan antara melanjutkan desain kurikulum prodi yang sudah ada atau menawarkan desain kurikulum baru yang memberikan inovasi dan pengalaman baru (new experience) bagi para mahasiswa, (Baharuddin, 2021). Penerapan Merdeka Belajar Kampus Merdeka (MBKM) sendiri didasarakan adanya tuntutan perkembangan ilmu pengetahuan, kompetensi dan keterampilan abad 21, hingga pentingnya perubahan dalam aktifitas perkuliahan.

MBKM sendiri merupakan desain lanjutan dari penerapan kurikulum program studi berbasis Kerangka Kualifikasi Nasional Indonesia (KKNI) yang berorientasi pada keutuhan capaian 
Respon Mahasiswa Proram Studi Pendidikan Matematika Universitas Flores pada Program MBKM, Sofia Sa'o, Lely Suryani, Hilaria M. Mbagho, Agustina Mei

kompetensi pembelajaran, meliputi unsur sikap/tata nilai, pengetahuan, keterampilan umum, dan keterampilan khusus. Prinsip utama dalam KKNI tentu saja bukan berapa banyak jumlah mata kuliah yang ditawarkan, tetapi seberapa besar kompetensi itu muncul dalam mata kuliah, (Fatmawati, 2020)

Munculnya kebijakan Menteri Pendidikan dan Kebudayaan yang didasarkan pada Peraturan Menteri Pendidikan dan Kebudayaan Republik Indonesia Nomor 3 Tahun 2020 Pasal 15 tentang Standar Nasional Pendidikan Tinggi, dengan adanya Merdeka Belajar dan Kampus Merdeka (MBKM) memberikan pergeseran pandangan di dunia pendidikan termasuk pendidikan di perguruan tinggi. MBKM bertujuan untuk mendorong mahasiswa memperoleh pengalaman belajar dengan berbagai kompetensi tambahan. di program studi dan/atau di luar kampus (Junaidi, dkk., 2020). Menurut Nadiem Makarim, konsep merdeka belajar dipilih karena terinspirasi dengan filsafat K.H Dewantara dengan esensi pendidikannya bermakna kemerdekaan dan kemandirian. Merdeka belajar dianggap relevan dan tepat dilaksanakan di era demokrasi pendidikan saat ini. Makna merdeka ini dapat diberlakukan bagi pendidik di kelas untuk bebas memilih metode mengajar yang tepat untuk anak didiknya dan merdeka memilih elemen-elemen yang terbaik dalam kurikulum. Makna kemerdekaan dan kebebasan merupakan pendidikan yang menekankan pada demokrasi pendidikan, (Nora.S, 2021)

Dengan adanya kebijakan pemerintah di atas, maka perguruan tinggi di Indonesia melakukan perubahan kurikulum. Dalam Kurikulum Merdeka Belajar dan Kampus Merdeka, mahasiswa diberikan kesempatan untuk mengikuti perkuliahan di luar program studi dalam perguruan tinggi yang sama selama satu semester atau setara dengan 20 sks, (Widayati et al., 2020). Untuk hal ini, perkuliahan terbatas pada mata kuliah wajib yang telah ditetapkan di universitas. Dari pemaparan di atas, terlihat bahwa pada program Merdeka Belajar Kampus Merdeka ini terdapat suatu inovasi belajar sehingga dapat menghasilkaan mahasiswa yang inovatif, kreatif dan sekaligus dapat mengembangkan potensi dirinya dalam bidang yang dipilih. Pelaksanaan di lapangan, mahasiswa dapat berperan sebagai pendipta kerja (job creator). Program studi pendidikan matematika FKIPUniversitas Flores adalah salah satu program studi yang sudah mengikuti kegiatan Merdeka Belajar Kampus Merdeka (MBKM) program mengajar di sekolah.

Beberapa artikel telah mengkaji dan membahas terkait program Merdeka Belajar Kampus Merdeka (MBKM) antara lain; Nora Susilawati (2021) menjelaskan tentang Merdeka Belajar Kampus Merdeka (MBKM) dalam pandangan filsafat pendidikan humanisme. Berikutnya Siti Mustaghfiroh (2020) yang membahas tentang konsep Merdeka Belajar Kampus Merdeka (MBKM) memiliki arah dan tujuan yang sama dengan konsep aliran filsafat pendidikan progresivisme John Dewey. Nurhayani, 2020 menguraikan tentang konsep kampus merdeka belajar di era revoluasi 4.0; selanjutnya Muslikh (2020) menulis tentang landasan filosofis dan analisis terhadap kebijakan merdeka belajar dan kampus merdeka. Sudaryanto (2020) meneliti tentang konsep Merdeka Belajar Kampus Merdeka dan aplikasinya dalam pendidikan bahasa dan sastra Indonesia. Sigit Priatmoko (2020) menjelaskan tentang relevansi kampus merdeka terhadap kompetensi guru era 4.0 dalam 
perspektif Experiential Learning Theory.

Dalam penelitian ini agak berbeda dengan penelitian sebelumnya yakni akan membahas tentang bagaimana respon mahasiswa program studi pendidikan matematika Universitas Flores pada program MBKM. Berdasarkan latar belakang tersebut, peneltian ini bertujuan untuk mengetahui Dampak Merdeka Belajar Kampus Maerdeka (MBKM) di Perguruan Tinggi Swasta: Survey pada Program Studi Pendidikan Matematika FKIP-Universitas Flores.

\section{METODE}

Menurut Bogdan dan Taylor penelitian kualitatif adalah prosedur penelitian yang menghasilkan data deskriptif berupa kata-kata tertulis atau lisan dari orang dan perilaku yang dapat diamati, (Lexy. $\mathbf{J}$ Moleong, 2013). Penelitian ini merupakan penelitian deskriptif dengan pendekatan kualitatif (Arikunto 2010), dengan metode survei. Data diperoleh dari populasi yakni 156 responden yang merupakan mahasiswa Program Studi Pendidikan Matematika Universitas Flores. Data dikumpulkan melalui kuesioner yang telah dibuat oleh Kementrian Pendidikan, Kebudayaan, Riset dan Teknologi melalui aplikasi SPADA Dikti. Teknik analisis data dimulai dari pengumpulan data kemudian dianalisis menggunakan analisis deskriptif. Data yang dianalisis bersumber dari data Primer melalui pemetaan hasil tiap butir pertanyaan yang digunakan dalam kuesioner. Semua analisis menggunakan standar baku yakni diagram hasil jawaban dari mahasiswa yang disajikan menggunakan informasi data statistik (Bethlehem 2009).

Hasil penelitian ini akan digunakan sebagai adaptasi atas kajian kegiatan merdeka belajar kampus merdeka tentang perencanaan, proses pembelajaran, penilaian dan evaluasi pembelajaran. Lebih lanjut, hasil penelitian ini akan digunakan untuk melihat kesesuaian terhadap kurikulum program studi yang telah ada serta menjadi acuan untuk merancang proses pembelajaran serta kerjasama akademik yang relevan (Baharudin, 2021). hasil tiap butir pertanyaan yang digunakan dalam kuesioner. Semua analisis menggunakan standar baku yakni diagram hasil jawaban dari mahasiswa yang disajikan menggunakan informasi data statistik (Bethlehem 2009).

\section{HASIL DAN DISKUSI}

Penelitian ini dilakukan untuk mengukur persepsi dan respon dari penerapan MBKM Program Studi Pendidikan Matematika FKIP - Universitas Flores. Responden yang dipilih merupakan seluruh populasi mahasiswa pada Program Studi Pendidikan Matematika, FKIP Universitas Flores. Gambaran responden berdasarkan Angkatan dapat dilihat pada Gambar 1.

Hasil penelitian ini diperoleh melalui metode survey dengan penjelasan deskriptif kuanlitatif yang dianalisis menggunakan informasi data statistik. Kuisioner Survei terdiri dari 22 butir pertanyaan dan pernyataan dengan pilihan jawaban yang disesuaikan dengan kebutuhan survey oleh tim SPADA Dikti. Survei akan terbagi dalam 2 bagian tergantung dari siswa memilih jawaban pada butir pertanyaan pertama kuesioner yang diberikan dalam online kuesioner. Bagian pertama ialah 
Respon Mahasiswa Proram Studi Pendidikan Matematika Universitas Flores pada Program MBKM, Sofia Sa'o, Lely Suryani, Hilaria M. Mbagho, Agustina Mei

mahasiswa yang yang menjawab kuesioner butir pertama mengetahui kebijakan baik seluruhnya, sebagian besar isi kebijakan maupun sedikit mengetahui, akan melanjutkan jawaban kuesioner ke nomor 2 hingga 22 yakni berupa permintaan kritik dan saran. Namun, jika mahasiswa menjawab belum mengetahui kebijakan MBKM pada butir pertama, maka mahasiswa tersebut akan melewati tahap pertanyaan $2-21$, dan langsung menjawab butir 22 yakni permintaan kritik dan saran untuk kemajuan penerapan kebijakan MBKM. Hasil pemetaan survey yang diperoleh dari data dapat dilihat pada Gambar 2.

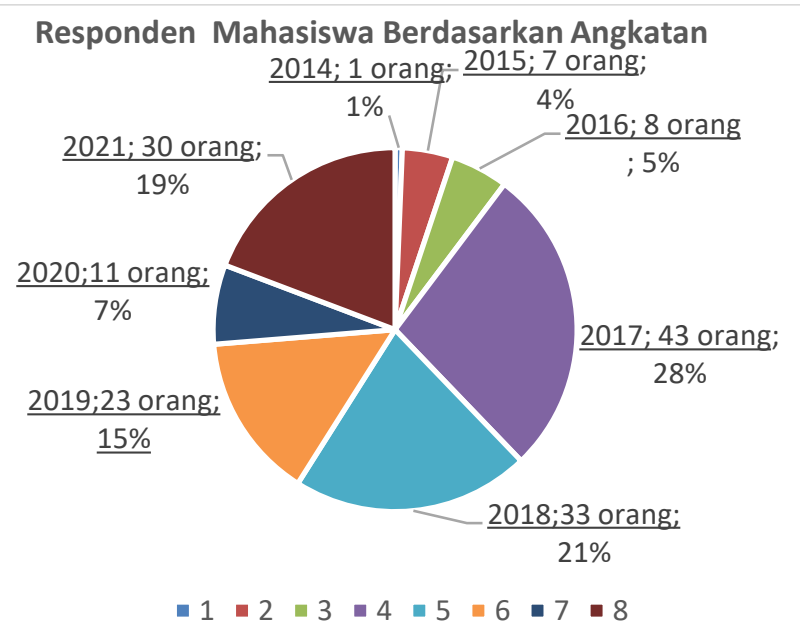

Gambar 1. Gambaran Responden (Mahasiswa) Program Studi Pendidikan Matematika

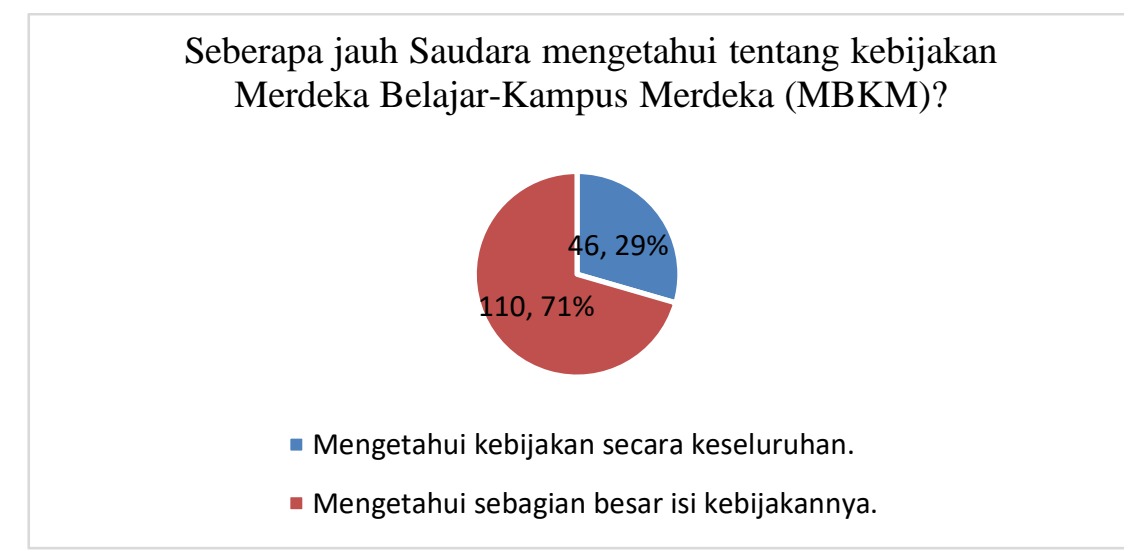

Gambar 2. Hasil Survei untuk Pengetahuan Mahasiswa Mengenai Kebijakan MBKM

Pada tahun 2020 Angkatan 1 sebanyak 14 mahasiswa Program Studi Pendidikan Matematika Universitas Flores lulus MBKM program mengajar di sekolah, maka dari Gambar 2 diperoleh dari analisis untuk melihat sejauh mana mahasiswa Program Studi Pendidikan Matematika mengetahui mengenai Kebijakan MBKM. Hasil survey menunjukan 110 mahasiswa atau sebesar $71 \%$ memilih mengetahui sebagian besar isi kebijakannnya dan sebanyak 46 mahasiswa atau sebesar 29\% mahasiswa memilih mengetahui kebijakan secara keseluruhan. Berdasarkan pilihan tersebut maka seluruh mahasiswa sebanyak 156 mahasiswa masih melanjutkan untuk pertanyaan 2 -22. 


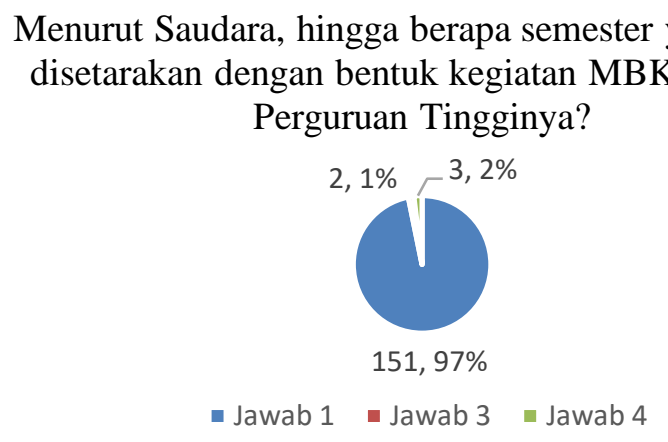

Gambar 3. Hasil Survei Mengenai hingga berapa semester yang dapat disetarakan kegiatan MBKM

Pada gambar 3 diperoleh dari analisis untuk melihat sejauh mana mahasiswa mengetahui hingga berapa semester yang dapat disetarakan dengan bentuk kegiatan MBKM di luar perguruan tinggi. Hasil survey menunjukan 2 mahasiswa atau 1\% memilih 3 semester, sebanyak 3 mahasiswa atau 2\% memilih 4 semester dan sebanyak 151 mahasiswa atau 97\% memilih 1 semester.

Menurut Saudara, hingga berapa sks yang dapat disetarakan dengan bentuk kegiatan MBKM di luar Perguruan Tingginya? Jawab: 12 sks

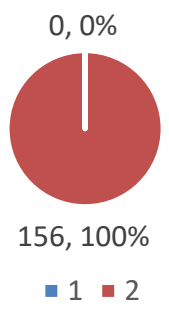

Gambar 4. Hasil Survei Mengenai hingga berapa sks yang dapat disetarakan kegiatan MBKM

Berdasarkan pengalaman yang dilaksanakan oleh 14 mahasiswa yang lulus MBKM program mengajar di sekolah angkatan 1, sebanyak 12 sks yang dikonversi dari Program Studi Pendidikan Matematika Universitas Flores, maka dari hasil survey pada gambar 4 di atas, sebanyak 156 mahasiswa atau $100 \%$ menjawab 12 sks.

Menurut saudara, apa media informasi untuk meningkatkan pemahaman kebijakan Merdeka Belajar-Kampus Merdeka (MBKM)? Mohon memilih 3 (tiga) yang terbaik berdasarkan peringkatnya.

- Kanal daring Kemendikbud (laman/website, media sosial)

- Kanal daring Perguruan Tinggi

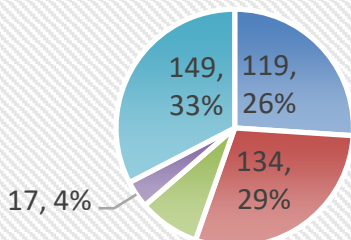

$38,8 \%$ (laman/website media sosial).

- Kanal komunikasi komunitas (misal: komunitas alumni, komunitas dosen).

- Kegiatan sosialisasi luring/daring yang diselenggarakan oleh Perguruan Tinggi.

- Media massa.

Gambar 5. Hasil Survei Mengenai informasi pemahaman kebijakan MBKM 
Respon Mahasiswa Proram Studi Pendidikan Matematika Universitas Flores pada Program MBKM, Sofia Sa'o, Lely Suryani, Hilaria M. Mbagho, Agustina Mei

Pada butir kuesioner gambar 5 di atas, ketika responden diminta untuk memilih 3 yang terbaik media informasi untuk meningkatkan pemahaman kebijakan MBKM, yang paling banyak memilih adalah media masa sebanyak 149 mahasiswa atau 33\%, selanjutnya 134 mahasiswa atau 29\% memilih kanal daring perguruan tinggi dan dilanjutkan memilih kanal daring kemendikbud sebanyak 119 mahasiswa atau 26\%, sebanyak 38 mahasiswa atau $8 \%$ memilih kanal komunikasi komunitas, dan sebanyak 17 mahasiswa atau 4\% memilih kegiatan sosialisasi luring/daring yang diselenggarakan oleh perguruan tinggi, sehingga pentingnya sosialisasi dalam penerapan MBKM yang dilakukan Perguruan Tinggi sebagai tempat mahasiswa belajar (Baharuddin, 2021; Fuadi \& Aswita 2021).

Apakah Program Studi Saudara mempunyai program terdahulu yang sesuai dengan bentuk kegiatan Merdeka Belajar-Kampus Merdeka (MBKM)?

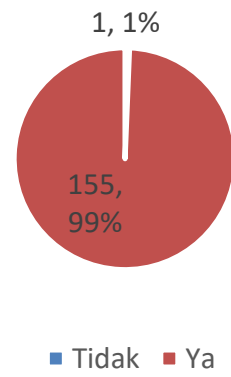

Gambar 6. Hasil Survei Mengenai program terdahulu yang sesuai MBKM

Pada gambar 6 diperoleh dari analisis untuk mengetahui apakah program studi pendidikan matematika mempunyai program terdahulu yang sesuai dengan bentuk kegiatan MBKM, sebanyak 155 mahasiswa atau 99\% menjawab ya dan hanya 1 mahasiswa atau $1 \%$ menjawab tidak, hal ini dikarenakan 1 mahasiswa tesebut tidak serius dalam pengisian kuisioner.

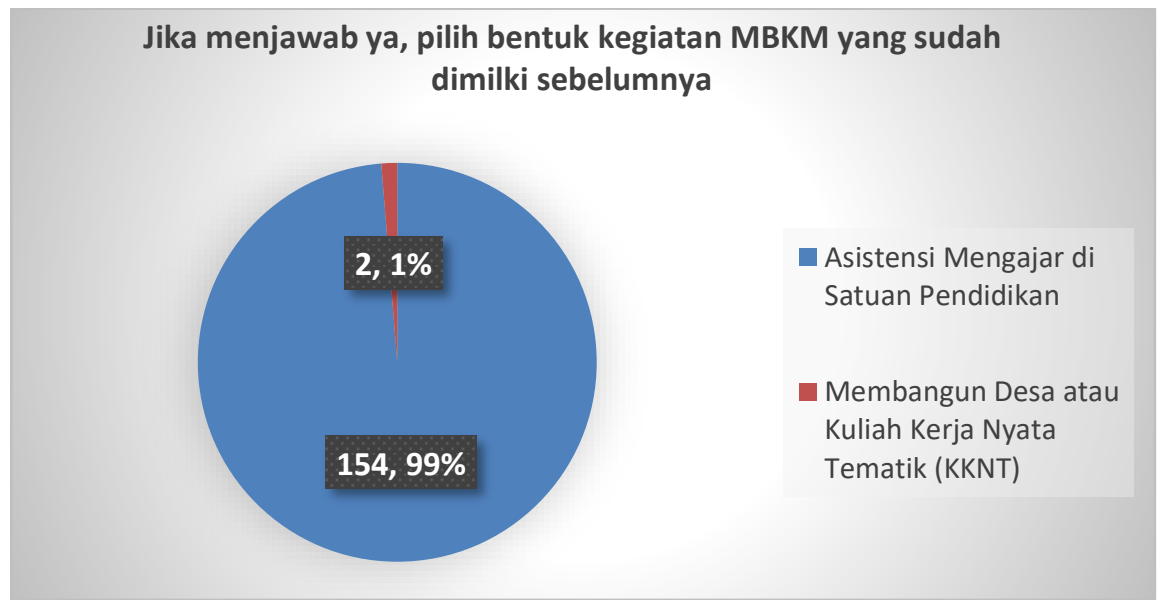

Gambar 7. Hasil Survei Mengenai program terdahulu yang sesuai MBKM

Program Studi Pendidikan Matematika adalah Program Studi yang dimiliki oleh Fakultas Keguruan dan Ilmu Pendidikan, dimana alumni akan menjadi seorang guru yang akan mengajar disatuan pendidikan. Oleh karena itu, hasil survey pada gambar 7 hasil analisis menunjukan bahwa 
sebanyak 154 mahasiswa atau 99\% memilih asistensi mengajar di satuan pendidikan, dan 2 mahasiswa atau $1 \%$ memilih membangun desa atau Kuliah Kerja Nyata Tematik (KKNT).

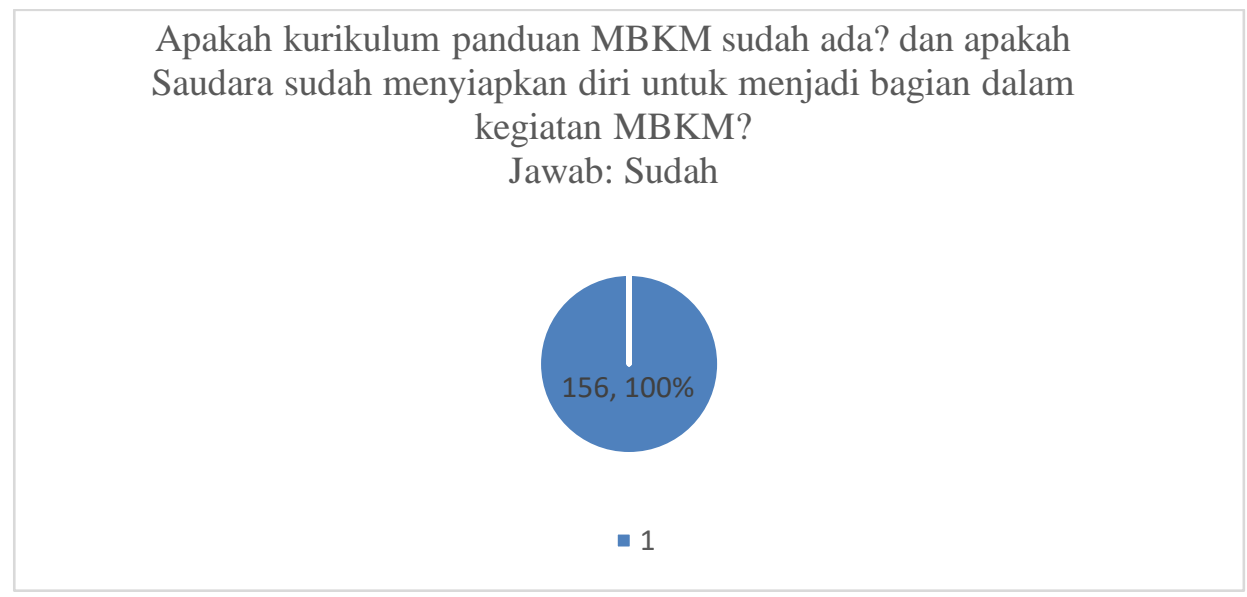

Gambar 8. Hasil Survei kesiapan kurikulum dan kesiapan diri dalam kegiatan MBKM

Gambar 8 diperoleh dari analisis untuk mengetahui apakah kurikulum panduan MBKM sudah ada di program studi pendidikan matematika, dari hasil survey sebanyak 156 mahasiwa menjawab ya, dan hasil survey tentang kesiapan diri untk menjadi bagian dalam kegiatan MBKM semua mahasiswa sebanyak 156 atau 100\% menjawab ya, ini artinya mahasiswa program studi pendidikan matematika sudah benar-benar menyiapkan diri dalam kegiatan MBKM, karena sebelumnya juga sudah ada mahasiswa yang lulus seleksi dan sudah melaksanakan kegiatan MBKM, dimana kegiatan dapat meningkatkan kompetensi, kemampuan, dan memberikan pengalaman nyata yang komprehensif sehingga dapat membiasakan diri mereka untuk siap terjun ke dunia kerja pada masa mendatang (Slavin, 2005).

Lebih lanjut, pada butir kuisioner kegiatan pembelajaran di luar program studi akan berimplikasi pada masa studi. Seluruh mahasiswa sebanyak 156 orang atau sebanyak $100 \%$ memilih tetap tepat waktu, bahkan ada pengalaman, pengetahuan dan wawasan yang dieroleh dalam kegiatan MBKM. Pada indikator kegiatan pembelajaran di luar kampus akan memberikan kompetensi tambahan seperti keterampilan dalam menyelesaikan permasalahan nyata yang kompleks, keterampilan dalam menganalis, etika profesi, dll, sebanyak 156 mahasiswa atau sebesar 100\% memilih ya sangat memberikan kompetensi tambahan. Selanjutnya pada indikator belajar di program studi lain akan memperluas perspektif dan memberikan kompetensi tambahan yang dibutuhkan, sebanyak 154 mahasiswa atau 99\% memilih ya, sedangkan menjawab mungkin hanya 1 orang atau $1 \%$ saja.

Selanjutnya pada pertanyaan terkait apa saja yang perlu dipersiapkan oleh mahasiswa agar implementasi MBKM berjalan optimal, hasil survey sebanyak 156 mahasiswa atau sebesar 100\% memilih bahwa ada 3 hal yang perlu dipersiapkan dalam kegiatan MBKM yakni; 1) mempelajari panduan MBKM dan kurikulumyang memfasilitasi MBKM, 2) mengikuti seleksi kegiatan dan 
menyiapkan syarat-syarat yang dibutuhkan, 3) proaktif dalam mempersiapkan kegiatan pembelajaran yang sesuai. Hasil survei tersebut dapat dilihat pada Gambar 9 berikut.

Menurut Saudara, apa saja yang perlu dipersiapkan oleh mahasiswa agar implementasi MBKM berjalan optimal?

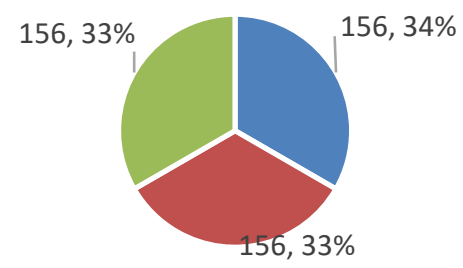

- Mempelajari panduan MBKM dan kurikulum yang memfasilitasi MBKM.

- Mengikuti seleksi kegiatan dan menyiapkan syarat-syarat yang dibutuhkan.

- Proaktif dalam mempersiapkan kegiatan pembelajaran yang sesuai.

Gambar 9. Hasil Survei kesiapan kurikulum dan kesiapan diri dalam kegiatan MBKM

Selanjutnya pada butir kuisioner apa manfaat jika anda mengikuti kegiatan MBKM dalam pengembangan kompentensi/keterampilan sebagai bekal bekerja setelah lulus, sebanyak 19 mahasiswa atau sebesar 12\% memilih cukup bermanfaat sedangkan sebanyak 137 mahasiswa atau sebesar $88 \%$ memilih sangat bermanfaat. Sedangkan pada indikator seberapa besar peningkatan softskill yang diperoleh setelah anda mengikuti kegiatan MBKM dalam pengembangan kompentensi/keterampilan sebagai bekal bekerja setelah lulus, dari hasil survey hanya 1 mahasiswa atau $1 \%$ memilih cukup baik, sebanyak 30 mahasiswa atau $19 \%$ memilih peningkatan dengan baik dan 125 mahasiswa atau sebesar 80\% memilih peningkatan dengan sangat baik, hal ini berdasarkan pengalaman dari 14 mahasiswa angkatan 1 yang telah mengikuti kegiatan MBKM, mengungkapkan bahwa peningkatan soft-skill yang diperoleh sangat besar sehingga dapat menjadi bekal dalam pengembangan kompetensi/ketrampilan sebagai bekal setelah lulus nanti. Selanjutnya pada indikator seberapa penting kegiatan MBKM untuk persiapan menghadapi masa paska kampus, sebanyak 134 mahasiswa atau sebesar $86 \%$ memilih sangat penting dan hanya 22 mahasiswa atau $14 \%$ memilih penting.

Menurut saudara, apa yang menjadi kekwatiran ketika melakukan kegiatan pembelajaran di luar kampus?
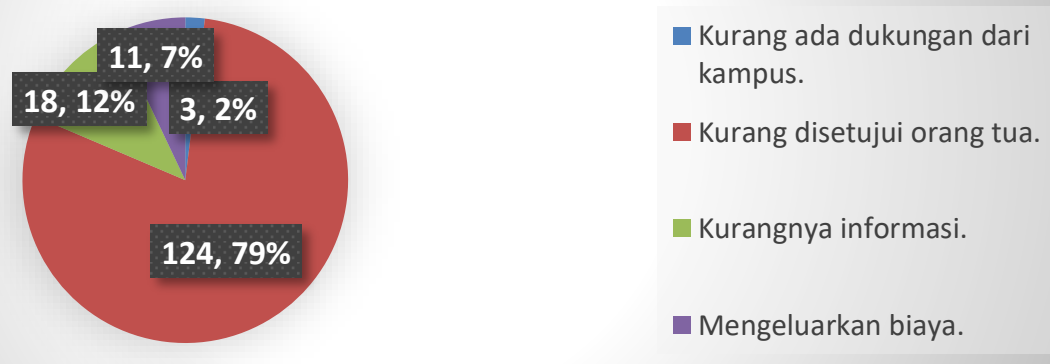

Gambar 10. Hasil Survei kekwatiran ketika melakukan kegiatan di luar kampus 
Gambar 10 diperoleh dari analisis kekwatiran ketika melakukan kegiatan pembelajaran di luar kampu, sebanyak 124 mahasiswa atau 79\% menjawab kurang disetujui orang tua, hal ini dikarenakan penempatan di sekolah yang berada dipelosok yang tidak memiliki jaringan sehingga terhambatnya komunikasi. Sebanyak 11 mahasiswa atau 7\% memilih mengeluarkan biaya, sebanyak 18 mahasiswa atau $12 \%$ memilih kurangnya informasi dan hanya 3 mahasiswa atau $2 \%$ memilih kurang dukungan dari kampus.

Menurut Saudara, kegiatan MBKM untuk perguruan tinggi sesuai dengan kebutuhan lulusan di masa mendatang?

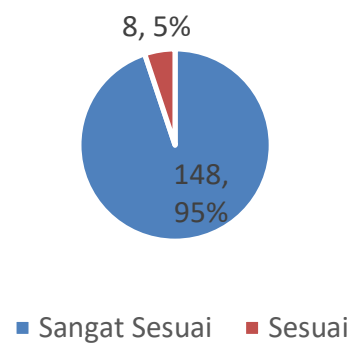

Gambar 11. Hasil Survei kebutuhan lulusan pada kegiatan MBKM

Lebih lanjut pada butir kuisoner pada gambar 11 di atas, kegiatan MBKM untuk perguruan tinggi sesuai dengan kebutuhan lulusan di masa mendatang, hasil survey sebanyak 148 mahasiswa atau sebesar 95\% memilih sangat sesuai, dan hanya 8 mahasiswa atau sebesar 5\% memilih sesuai hal ini menunjukan bahwa program MBKM sangat diminati oleh mahasiswa. Selanjutnya pada indikator ketertarikan terhadap program MBKM yang diadakan oleh Direktorat Jenderal Pendidikan Tinggi, Riset, dan Teknologi, hasil survey sebanyak 156 mahasiswa atau sebesar 100\% memilih sangat tertarik dengan kegiatan MBKM, Respon yang positif ditunjukan oleh responden dalam penelitian ini, menunjukan bahwa mahasiwa tertarik untuk mengikuti banyak program yang ada pada kebijakan MBKM. Mahasiswa menjadi lebih peduli terhadap apa yang harus mereka persiapkan dimasa depan (Mariati, 2021)..

Setelah mengetahui secara detail tentang program MBKM, apakah anda akan merekomendasikan program ini untuk kolega saudara?

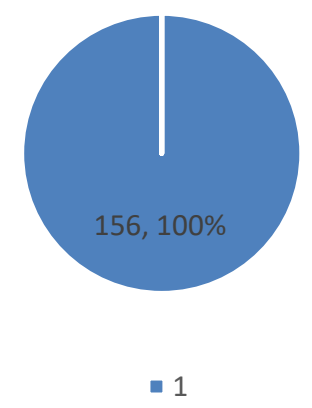

Gambar 12. Hasil Survei kebutuhan lulusan pada kegiatan MBKM 
Respon Mahasiswa Proram Studi Pendidikan Matematika Universitas Flores pada Program MBKM, Sofia Sa'o, Lely Suryani, Hilaria M. Mbagho, Agustina Mei

Sedangkan pada butir pertanyaan kuisioner gambar 12 di atas, apakah setelah mengetahui secara detail tentang program MBKManda akan merekomendasikan program ini untuk kolega saudara, hasil survey sebanyak 156 mahasiswa atau sebesar 100\% menjawab sangat merekomendasi. Desain program kebijakan MBKM menjadi salah satu metode yang diharapkan memnuhi tantangan program studi pendidikan biologi Universitas Flores untuk menciptakan output yang melek akan kemajuan Peningkatan IPTEK, dan mampu bersaing dalam kemajuan global (Slavin, 2005). Program MBKM memberi kebebasan dan otonomi kepada lembaga pendidikan untuk memberikan peluang kepada mahasiswa untuk memilih bidang yang mereka minati. Kampus merdeka diharapkan dapat menjadi pembelajaran yang otonom dan fleksibel sehingga tercipta kultur belajar yang inovatif dan sesuai dengan kebutuhan mahasiswa (Slavin, 2005).

\section{KESIMPULAN}

Dari hasil penelitian survey ini menunjukan bahwa mahasiswa program studi pendidikan Matematika, FKIP Universitas Flores memberikan respon yang positif terhadap program Merdeka Belajar Kampus Merdeka (MBKM). Platform sosialisasi baik daring maupun luring oleh Perguruan Tinggi menjadi platform yang paling dipilih oleh siswa dalam mengtahui semua program dan kebijakan MBKM, Dominan siswa telah menyiapkan diri untuk siap mengikuti program MBKM. Program asistensi mengajar disatuan pendidikan menjadi program favorit program MBKM yang paling dominan yang diminati mahasiswa karena Program Studi Pendidikan Matematika adalah Program studi dibawah naungan Fakultas Keguruan dan Ilmu Pendidikan dimana mahasiswa pada semester VI wajib memprogram mata kuliah Praktek Pengalaman Lapangan (PPL) dan setelah lulus nanti mahasiswa akan menjadi seorang guru yang akan mengajar di satuan pendidikan. Sementara itu banyak saran yang juga dituliskan oleh mahasiswa yakni agar program MBKM dapat diterapkan pada semester awal perkuliahan.

\section{UCAPAN TERIMA KASIH}

Ucapan terima kasih disampaikan kepada Direktoral Jendral Pendidikan Tinggi, Riset dan Teknologi, Kementrian Pendidikan, Kebudayaan, Riset dan Teknologi yang telah mendanai penelitian dampak MBKM ini melalui program penelitian MBKM dan pengabdian berbasis riset menggunakan bantuan pendanaan program penelitian kebijakan Merdeka Belajar Kampus Merdeka dan pengabdian kepada masyarakat berbasis hasil penelitian perguruan tinggi swasta tahun 2021. Ucapan terima kasih juga disampaikan kepada Universitas Flores dan Lembaga Penelitian dan Pengabdian Kepada Masyarakat (LP2M) Universitas Flores yang memberikan kesempatan kepada tim peneliti untuk melakukan penelitian ini.

\section{REFERENSI}

Baharuddin, M. R. (2021). Adaptasi Kurikulum Merdeka Belajar Kampus Merdeka ( Fokus : Model MBKM Program Studi ). 4(1), 195-205. 
Bethlehem, J. (2009). Applied Survey Methods: A Statistical Perspective. Hoboken: John Wiley \& Sons, Inc. https://doi.org/10.1002/9780470494998

Fatmawati, E. (2020). Dukungan Perpustakaan Dalam Implementasi "Kampus Merdeka dan Merdeka Belajar." Jurnal Pustaka Ilmiah, 6(2), 1076-1087. https://doi.org/https://doi.org/10.20961/jpi.v6i2.46682

Fatah, Amir. (2021). Eksplorasi Dukungan Industri Mitra Dalam Pelaksanaan Magang Pada Program Merdeka Belajar Kampus Merdeka. Prosiding Seminar Nasional Teknologi Pembelajaran Universitas Negeri Malang Tahun 2021. 1(1), 282-290

Fuadi, T. M. (2021). KONSEP MERDEKA BELAJAR-KAMPUS MERDEKA (MBKM) : APLIKASINYA DALAM PENDIDIKAN BIOLOGI. Prosiding Seminar Nasional Biotik, 9(1), $183-200$

Fuadi, T. M. \& Aswita, D. (2021). Merdeka Belajar Kampus Merdeka (MBKM) : Bagaimana Penerapan Dan Kedala Yang Dihadapi Oleh Perguruan Tinggi Swasta Di Aceh. Jurnal Dedikasi Pendidikan, 5(2), 603-614

Junaidi, Aris, dkk. (2020). Panduan Penyusunan Kurikulum Pendidikan Tinggi di Era Industri 4.0 Untuk Mendukung Merdeka Belajar-Kampus Merdeka. Jakarta: Direktorat Jendral Pendidikan Tinggi Kementrian Pendidikan dan Kebudayaan

Kamalia, P., \& Andriansyah, E. (2021). Independent Learning-Independent Campus (MBKM) in Students' Perception. Jurnal Kependidikan: Jurnal Hasil Penelitian dan Kajian Kepustakaan di Bidang Pendidikan, Pengajaran dan Pembelajaran, 7(4), 857-867. doi:https://doi.org/10.33394/jk.v7i4.4031

Krisnanik, E., Saphira, Q., \& Hesti Indriana, I. (2021). Desain Model MBKM Dan Kolaborasi Kerja Sama Model Pentahelix Guna Meningkatkan Daya Saing Lulusan. Proceeding KONIK (Konferensi Nasional Ilmu Komputer), 5(1), 138-142. Diambil dari https://prosiding.konik.id/index.php/konik/article/view/40

Kurnia, dkk. (2021). Pangan Fungsional Untuk Proyek Independen Kkn-Tematik Di Masa Pandemi COVID-19. SELAPARANG.Jurnal Pengabdian Masyarakat Berkemajuan. 5(1), 608-615. https://doi.org/10.31764/jpmb.v5i1.5749

Lexy. J Moleong. (2013). Metode Penelitian Kualitatif. Edisi Revisi, Bandung.

Mariati, M. (2021). Tantangan Pengembangan Kurikulum Merdeka Belajar Kampus Merdeka Di Perguruan Tinggi. Prosiding Seminar Nasional Teknologi Edukasi dan Humaniora 2021, ke-1. 1(1), 747-758. https://doi.org/10.53695/sintesa.v1i1.405

Muhsin, H. (2021). Kampus Merdeka Di Era New Normal. Dalam: A. Muslihat dkk. Masa Depan Kampus Merdeka \& Merdeka Belajar: Sebuah Bunga Rampai Dosen. 143. Bintang Visitama Publisher.

Nora.S. (2021). Merdeka Belajar dan Kampus Merdeka Dalam Pandangan Filsafat Pendidikan Humanisme Nora Susilawati Universitas Negeri Padang Email: 
Respon Mahasiswa Proram Studi Pendidikan Matematika Universitas Flores pada Program MBKM, Sofia Sa'o, Lely Suryani, Hilaria M. Mbagho, Agustina Mei

norasusilawati1973@gmail.com.2(3),203-219.

Putri, R. A., dkk. (2021). Analisis Kompetensi Guru Mahasiswa Pendidikan Bahasa Dan Sastra Indonesia Universitas Negeri Medan Dalam Program Magang Kependidikan MBKM. BAHAS,32(4), 371-384. https://doi.org/10.24114/bhs.v32i4.30546

Rochana, R. Darajatun, R. M. \& Ramdhany, M.A. (2021). Pengaruh Implementasi Kebijakan Kampus Merdeka terhadap Minat dan Keterlibatan Mahasiswa. Journal of Business Management Education 6(3) 11-21. https://doi.org/10.17509/jbme.v6i3.40165

Rodiyah, R. (2021). Implementasi Program Merdeka Belajar Kampus Merdeka di Era Digital dalam Menciptakan Karakter Mahasiswa Hukum yang Berkarakter dan Profesional. Seminar Nasional Hukum Universitas Negeri $\quad$ Semarang, 7(2), https://doi.org/10.15294/snhunnes.v7i2.737

Rohiyatussakinah, I. (2021). Implementation of MBKM and the Relationship of Curriculum Policy based on a Case of EFL Education in Japan. Journal of English Language Teaching and Literature (JELTL), 4(2), 39 - 50. https://doi.org/10.47080/jeltl.v4i2.1

Slavin, R. E. (2005). Learning:, Cooperative teori, riset, dan praktek. Bandung: Nusa Narulita, Media. (Diterjemahkan oleh Learning:, Yusron dari Cooperative Theory, Research and Practice). Allyn and Bacon.

Suwandi, S. (2020). Pengembangan Kurikulum Program Studi Pendidikan Bahasa (dan Sastra) Indonesia yang Responsif terhadap Kebijakan Merdeka Belajar-Kampus Merdeka dan Kebutuhan Pembelajaran Abad ke-21. Dalam: Prosiding Seminar Daring Nasional: Pengembangan Kurikulum Merdeka Belajar Program Studi Pendidikan Bahasa Indonesia, 21 Oktober 2020, pp 1-12. https://ejournal.unib.ac.id/index.php/semiba/article/view/13356

Widayati, W., Amalia, R., Pendidikan, I., \& Dahlan, U. A. (2020). Konsep Merdeka Belajar-Kampus Merdeka dan Aplikasinya dalam Pendidikan Bahasa ( dan Sastra) Indonesia. 78-93.

Wijayanto, A. (2021). Implementasi dan Problematika Merdeka Belajar. OSF Preprints. https://doi.org/10.31219/osf.io/yshk6. 